\section{Biological Membranes}

Sir,-Your Molecular Biology Correspondent, in commenting (Nature, 227, 1294; 1970) on some interesting recent model studies relevant to biological membranes, leaves the impression that it is a new idea of general importance in transport studies that the relative energies of hydration of the alkali cations may be responsible for their differing affinities for anionic or polar sites. I would like to correct this impression by drawing attention to the extensive studies by Eisenman ${ }^{1}$ of the origins of ionic specificity which include a quantitative treatment of the dependence of ionic specificity on hydration energy.
Eisenman's work during the last decade has been superbly reviewed, with special reference to its validity in biology, by Diamond and Wright ${ }^{2}$.

Yours faithfully,

Department of Biology,

\section{Martin Davies}

University of York,

Heslington, York.

${ }^{1}$ Eisenman, G., in Symposium on Membrane Transport and Metabolism (edit. by Kleinzeller, A., and Kotyk, A.), 163 (Academic Press, New rk, 1981).

${ }^{2}$ Diamond, J. M., and Wright, E. M., Ann. Rev. Physiol., 31, 581 (1969).

\title{
Announcements
}

\section{University News}

Mr J. E. L. Farradane has been appointed the first director of the Centre for Information Science of the City University.

Dr G. W. Bisset, National Institute for Medical Rescarch, has been appointed to the chair of pharmacology, St Thomas's Hospital Medical School, University of London. The title of professor of preventive dentistry has been conferred on Dr M. N. Naylor in respect of his post at Guy's Hospital Medical School and that of professor of chemistry has been conferred on Dr Mary $\mathbf{R}$. Truter in respect of her post at University College.

Dr I. A. Menzies, University of Manchester Institute of Science and rechnology, has been appointed to the new chair of matcrials technology in Loughborough University of Technology.

Professor Frank Morton has been appointed to a personal chair in chemical engineering in the University of Manchester. Mr M. G. G. Israels has been appointed professor (part-time) of clinical hamatology and Dr S. Thomas has been appointed to a chair of physiology.

\section{Appointments}

Mr Bryan Rofe has been appointed director of the Antarctic Division of the Commonwealth Department of Supply, Melbourne.

Lord Drumalbyn has been appointed to succeed Lord Bessborough as deputy chairman of the Metrication Board.

Sir Brian Windeyer, vice-chancellor of the University of London, will be chairman of the new National Radiological Protection Board, established to advance knowledge and provide information on protection from radiation hazards. Members of the board include Sir Charles Cunningham, UKAEA; Mr J. G. Duncan, MRC; Professor N. Feather, University of Edinburgh; Mr F. W. Fenning, AERE; Dr E. E. Pochin, MRC Clinical Research Department; Dr Derek Pringle, Nuclear Enterprises Limited; Professor R. E. Steiner, University of London Postgraduate Medical School.

\section{Miscellaneous}

Professor W. T. Singleton, University of Aston in Birmingham, has been made the first Distinguished Foreign Colleague of the American Human Factors Society.
Mr J. M. Lumley of Monash University has been awarded a Rutherford Scholarship for three years for work in low temperature physics at the Cavendish Laboratory, Cambridge.

Professor G. Melchers of the Max-Planck Institut für Biologie, D 74 Tübingen, Correnstr. 41, would like to hear from anybody who is engaged in tho culture of haploid plants from anthers. This information would be appreciated because an EMBO workshop on this topic is planned for next year.

Applications are invited for two Ramsay memorial fellowships, a British (general) fellowship and a fellowship limited to candidates educated at the Universities of Glasgow or Strathclyde or who propose to work there. The fellowships are normally tenable for two ycars. Further information can be obtained from the Joint Honorary Secretaries, Ramsay Memorial Fellowships Trust, University College London, Gower Street, London WCl.

The Geological Society of Uganda was established last month at Makerere University, Kampala. The society aims to encourage the study of the earth sciences, particularly of and in Uganda, and hopes to sponsor symposia and excursions. Mr C. E. Tamale-Ssali is president of the society, and members of council include Professor $\mathbf{R}$. Macdonald (hon. secretary), Dr K. Tinkler (hon. treasurer), Mr J. E. N. Kagule Magambo (hon. editor), Mr M. D. Gruikshanks and Mr E. S. Balaba. Further information can be obtained from Dr $\mathrm{K}$. Tinkler, PO Box 7062, Kampala, Uganda.

FrRatUM. The electronic processing mentioned by our Matcrials Science Correspondent (Nature, 228, 19; 1970) was developed at the Standard Telecommunications Laboratories, Harlow, and not at the Services Electronic Research Laboratory.

Erratum. In the review "Scavenging Cells" by F. Jacoby (Nature, 228, 188; 1970) the word "macrophage" on lines 1 and 2 of the third paragraph should read "macrophages".

Erratum. In her written answer in the House of Commons on July 20 (Nature, 227, 431 ; 1970), Mrs Margaret Thatcher said that the Government hopes to increase the present annual number of preclinical entry places to medical schools from 2,700 to 3,700 by 1975 . This was mistakenly quoted as an increase of between 2,700 and 3,700 places. 